\title{
Soft Power or Neo-colonialist Power? - African Perceptions of the EU
}

\author{
Siegmar Schmidt ${ }^{1}$ \\ ${ }^{1}$ Institute of Social Sciences, University of Koblenz-Landau, Landau, Germany \\ Correspondence: Siegmar Schmidt, Institute of Social Sciences, University of Koblenz-Landau, Kaufhausgasse 9, \\ Landau 76829, Germany. Tel: 49-6341-2803-8413. E-mail: schmidts@uni-landau.de
}

Received: November 24, 2011 Accepted: April 26, 2012 Online Published: July 1, 2012

doi:10.5539/res.v4n3p100

URL: http://dx.doi.org/10.5539/res.v4n3p100

\begin{abstract}
This article analyses African perceptions of the EU's policy toward Africa from a constructivist research perspective. From this perspective perceptions are important because they contribute to a foreign policy identity. The interaction of self-ascribed roles with external perceptions and expectations creates a foreign policy identity which manifests in foreign policy roles such as "civilian power". The main questions are: How do African elites and Africans at large perceive the European Union (EU)? What is the image of the EU in Africa? The empirical basis is characterised by deficits. The article gives a brief overview on historical legacies and the current interregional relations. In the following it assesses African perceptions of three key areas on the EU Africa policy: The EU's promotion of democracy and human rights, the EU's role in trade relations and the EU's policy in the field of peace and security. The following conclusion can be taken from the investigation: The EU is neither fully viewed as a soft-power nor as a neo-colonialist power. The EU's self-ascribed role is not fully accepted in Sub-Saharan Africa.
\end{abstract}

Keywords: European Union foreign policy, African perception, democracy promotion

\section{Introduction: The Civilian Power Image of the EU}

There is a broad consensus among students of European integration and international relations about the foreign policy identity of the EU: The EU is described as a non-state, value driven and normative actor and as a civilian power. The role concept of a civilian power implies that soft power dominates over hard power in the case of the EU. From this perspective EU foreign policy is not driven by the political ambitions to be a military power but aims to contribute to the civilization of international relations within the United Nations system and values (Maull 2006). The civilian power concept uses constructionist understanding of identity building.

The geographic focus of EU external relations lies on its neighbourhood, as the European Security Strategy (2003: 8) argues: "It is in the European interest that countries on our borders are well governed." The EU therefore claims to transform neighbouring states by supporting democratisation, respect for human rights and good governance. The civilian power concept has reached prominence but has been contested recently (Bono 2006), in particular for the progress with the European Security and Defence Policy (ESDP). Whereas some observers view a militarization of the European Union's foreign policy, others argue that ESDP operations are aiming at keeping peace and producing international order (Maull 2006: 167). The assumption of the unique character of the EU as an external actor and its normative rhetoric has lead to a lively debate on the EU role and its characteristics in international relations (see Elgström/Smith 2006). Other observers do not negate the normative character of EU foreign policy but they view the EU also as a trading power (Elgström 2007). They point out that in contrast to its limited military capabilities and the structural difficulties of the ESDP, the EU is a key player and possibly leading power on a global level in trade relations (WTO). From this perspective the EU is seen as an egoistic trading power with primarily economic interests. The Marxist school of thinking even argues that the EU must be considered as an imperialist power that exploits Africa through unfair trade relations and protectionist policies.

The aim of this article is to investigate perceptions of the EU in Africa: How do African elites and Africans at large perceive the European Union (EU)? What is the image of the EU in Africa? Due to the lack of empirical data on perceptions and mass opinions, the conclusions can only be tentative. The article begins with a brief discussion about the deficits in research. The following part gives a brief introduction into historical legacies. Slave trade and 
colonialism are root causes for a collective trauma in Africa leading often to mistrust on the African side and a feeling of responsibility among many Europeans (Note 1). There is a clear tendency visible in the relations to include more and more political issues into relations which had been dominated by trade and aid for decades. Section three presents findings on three aspects of African perceptions of the EU. First, African views of the EU's efforts to promote democracy and human rights will be extensively discussed. Special attention will be given to the question of how South Africans view the EU. Secondly, African views of EU trade policy; in particular the EPAs will be reviewed. Thirdly, African views on the EU's engagement in peace and security matters on the continent will be described. The empirical findings presented in these parts are borrowed partly from the analyses of Lucarelli/Fioramonti (2010) and Fioramonti (2009). And fourthly, the question of whether or not the EU is regarded as a model for the AU will be briefly addressed.

\section{The Theoretical Lens of This Article}

This article is based on a moderate constructivist approach to foreign policy analysis. The approach follows the constructivist line of thinking in the sense that the analysis is based on a constructivist understanding of foreign policy which views foreign policy behaviour largely as the result of specific identities. The constructivist approach can be termed moderate for its argumentation is based on empirical analysis and tries to discover causalities.

The underlying theoretical assumption of this article is that a cohesive and accepted identity is a precondition for actorness. The actorness manifests itself in certain foreign policy roles (for role theory see Wæver 2005). The ongoing debate whether the EU can become a global actor must therefore be connected with the debate on its foreign policy identity. For the European Union a pronounced foreign policy identity is even more important since it has compared to nation states much weaker common features (history, language etc.) as a basis for a common identity. Foreign policy identity is on the one hand based on values, norms and principles of the actor. From the constructivist angle, every foreign policy identity bases on a cohesive set of norms and principles which allows for the formulation of concrete interests.

On the other hand, identity is the result of communicative interaction between oneself and the external world. Chaban/Elgström/Holland (2006: 247) state that identities in form of foreign policy role "are created through continuous interaction between own role conceptions and structurally based expectations" by other actors.

This article does not describe the EU's ideas and perception of its role in the world such as value driven actor, normative power or civilian power. Thereby, this article does not describe the contents of the efforts by the EU, in particular the EU Commission to create a unique foreign policy identity construction. As aforementioned there is a broad consensus on the normative dimension on EU foreign policy. From this perspective the foreign policy identity of the EU as a civilian power is a result of the EU's self-ascribed role: the EU presents itself in the European Security Strategy (2003) as a "force for good" (Bailes 2008: 115). The focus of this article lies on the second dimension of identity creation: the external perception of the EU policy towards Africa by African politicians and the African Union. Beside its significance for the construction of the EU foreign policy identity, the study of external perceptions and expectations can inform us about whether the proclaimed aims of the EU foreign policy are met in reality and what impacts certain policies have had on the image of the EU (Chaban/Elgström/Holland 2006: 248). The way other actors perceive the EU also enhances the legitimacy and credibility of the Union and can create support and followers for EU policies (Elgström 2007: 952).

\section{The Research Gap}

Relations between the EU and Africa (Note 2) have been subject to social science research for a longer time, especially with a focus on trade and economic relations. The more recent literature has included also political and diplomatic relations to a much larger extent than before. But surprisingly, the African perception of the EU is an under-researched field. It seems that there is not much scholarly interest in African perceptions. Although the EU is the most important donor of aid, and compared to other intercontinental relations the EU-Africa relations consist of a dense network covering economic, diplomatic and security relations only a handful of studies investigate African perceptions. The most important study was published by Lucarelli/Fioramonti in 2010. This edited volume offers three case studies on African perceptions of the EU and views from South Africa (compared with Brazilian and Indian views) on the EU policy toward Africa. Whereas the chapter on South Africa is based on quantitative survey data and the analysis of press coverage, the other two case studies are methodologically based on interviews with African officials and the analysis of newspaper articles and documents. Most case studies in the volume edited by Lucarelli/Fioramonti (2010) (see also Elgström 2007) are exclusively elite-focused and the views of populations at large are not covered.

The vast majority of African populations are to a large extent unaware of foreign policy issues in general and of EU politics in particular (Note 3). There is not much data available about what Africans, especially in smaller countries, 
think on international politics or even African politics. From my experience, international politics are too remote in countries where many people struggle for their daily survival. Whether or not this will change with the skyrocketing number of mobile phones and internet connections is not clear. The lack of quantative, representative data is also true for elites' attitudes towards foreign policy issues. An exception is the study by Kotzé/Steyn (2003). They interviewed over 100 members of African elites (from politics, media, civil society) in South Africa, Nigeria, Senegal, Algeria, Kenya, Uganda, and Zimbabwe. According to their survey data on elite knowledge about the New Partnership for Africa's Development (NEPAD) and the AU as well as on the support for these indigenous African projects, knowledge gaps were also to be noticed even within elites. Another finding was that many respondents supported the principles of NEPAD and the AU but were pessimistic about whether they could cope with Africa's challenges.

But also in the EU many citizens would be unable to identify specific EU foreign policy issues and actions due to complexities and fragmentation of foreign and defence policy making (Note 4) and the dominance of the nation-state in these spheres. Widespread disappointment about the EU's silence on the changes in Egypt, Tunisia and Libya is rarely understood as a result of internal EU-conflict between member states with vested economic interests and member states with a more value-oriented policy. A higher grade of attention might be identified if personalities ("faces") are involved, for instance the discussion about Catherine Ashton when she became the Representative of EU foreign policy.

In addition, and according to my knowledge, there are so far no studies available on public discourses on the EU in African countries. This can be attributed to the structure of the political sphere in many countries where foreign policy is only subject to a few specialists and where a general discourse culture on political matters is underdeveloped. The situation is different in more advanced countries with international aspirations such as South Africa and Nigeria where foreign policy issues play a larger role in public debate.

\section{The Relations between $E U$ and Africa}

\subsection{The Historical Legacy}

Africa and Europe are connected by history. It is first and foremost largely a history of domination and intrusion. Africans fell first victim to the slave trade beginning at the end of the $15^{\text {th }}$ century and second to European colonialism reaching its peak at the end of the $19^{\text {th }}$ century. Whereas the slave trade was organized by Arabian and African traders and their European and American counterparts, colonialism was to a much greater extent a project of European imperialist powers. The Berlin Conference of 1884/85 with Chancellor Bismarck as an "honest broker" between the competing powers fixed the partition of Africa for the interests of imperialist European powers. Britain, France, Belgium, Portugal, Italy, and even latecomer Germany received "their fair share"-colonies. The reasons for colonialism were multifaceted and cannot be discussed here, because the long-term effects are of prior interest for this article.

The experience of European intrusion, the destruction of African societies and systems of governance, and the humiliation Africans faced, form a central part of the collective memory of Africans. With only few exceptions Ethiopia was liberated from Italian domination by Allied forces in 1941 and became independent - independence was achieved after WW II during the 1950ies and 1960ies. The decolonisation process started with Ghana, the former Gold Coast in 1957 and took different paths: Whereas the way to independence was a smooth transition in Uganda, a violent struggle including the Mau-Mau revolt took place in neighbouring Kenya. Belgian colonialists left the Congo in haste and leaving only a handful of professionals to lead the vast country. Portugal, itself a small country, succeeded to maintain Mozambique and Angola under colonial tutelage against armed guerrilla movements up to 1974 and 1975 respectively and left the countries because a democratization process started in Portugal itself. The Anglophone settler colonies in Rhodesia (from 1979 Zimbabwe), Namibia, and South Africa resisted pressure for change even longer and managed a more or less peaceful, negotiated transition after years of armed struggle. These few examples emphasise that the experience of colonialism and decolonisation was different from country to country with respect to the timeframe, the atrocities experienced (Note 5), and the mode of transition. European policies in Africa therefore face historical legacies leading toward a consciousness of responsibility or even moral guilt on the side of many European politicians and elites. From a psychological perspective, the general willingness to provide development aid can be interpreted as a kind of compensation.

\subsection{Aid, Trade and the Promotion of Values - Components of EU Africa Policy}

There is a long history of EU interregionalism (for the concept see Hettne/Söderbaum 2005) with Africa. For decades, the nucleus of European policies towards Africa consisted of a dense network of development aid and trade relations. The EU-Commission and EU member states are by far the largest donor of Official Development Aid (ODA) to Africa: approximately $60 \%$ of the global ODA for Africa stems from the EU. 
The first formalised agreement was signed as early as in 1963 in Yaoundé (Cameroon). The four Lomé-Conventions signed between the EU and a growing number of the ACP (African-Caribbean-Pacific) countries between 1975 and 1995 created the basis for highly institutionalized relations. The European Economic Community (EEC) and later the European Community (EC) offered guaranteed fixed sums of non-reimbursable development aid on an annnual basis, some advantages in trade, and special funds designed to stabilize commodity prices. The EU regarded the Lomè-agreements as a model for North-South cooperation. Critics argued that the funds were too limited, the role of African states as commodity exporters was even prolonged because the diversification of exports was not fostered, and that some "sensitive" agrarian goods were excluded from the access to the EEC market. A negative side effect of the long-standing trade and aid relations was the emergence of a dense network consisting of EEC administrators and their counterparts in the recipient countries. Their interest was to maintain the relations despite the disappointing results: most African countries remained underdeveloped and dependent on aid and the export of commodities. With the exception of Mauritius (textile production) African countries were not able to benefit from marked access to the European markets. At first sight the annual Lomé "allocations" for the African countries ranging from 20 and 200 Mill. US\$ seem rather moderate, but against the background of low annual budgets this "free" or unconditioned grants were significant in financial terms.

Politics was largely excluded from the relations. Only in the case of Idi Amin's despotic rule in Uganda the EEC took action after massive British diplomatic interventions. After lengthy discussions the EC suspended aid to the brutal regime. Politics came into play only gradually. The interim review of the Lomé IV agreement from 1995 saw the introduction of a suspension clause (Art. 366) in cases of a country violating the fundamental principles of cooperation - human rights, democracy and good governance. This important amendment to the Lomé-Convention confirmed the EC-conditionality. Political conditionality became an important policy instrument in the 1990ies when the end of the Cold War - the sea change in international politics - allowed western donors to refrain from supporting states only for strategic and ideological reasons. This new political leverage for donors was used by them to be more uncompromising in the case of serious human rights violations. From 1992 all relations between the EU and other states were subject to the principle of respect for human rights and democracy. Parallel to conditionality, the EU strengthened its efforts to promote human rights and democracy by "positive measures", i.e. the support for democratic elections, civil society, and democratic institutions. The main instrument became the European Initiative for Democracy and Human Rights (EIDHR) (Note 6) through which the funds were channelled mainly to NGOs serving as implementing agencies. The Union became active in electoral observation (Motsamai 2010), often in cooperation with international organizations (UN, UNDP) and other governments.

The Cotonou-Agreement signed in Benin's capital in 2000 brought the so far biggest changes in economic and political relations, redefining the EU's objectives and strategies. The existence of the Cotonou-Agreement is in general remarkable because Africa lost much of its economic importance for the EU states: trade (import and export) with Africa accounted in 2000 for roughly 2.5-3.0\% only of the total EU trade which had been around 9\% in 1970.

In economic terms the EU had to adapt its non-reciprocal (preferential) trade relations to WTO-rules. Nevertheless the EU's successful claim for an exception clause ("waiver"), African states will have to provide more unrestricted access to their markets in the mid-term future. The main aim of the EU is to promote the establishment of Economic Partnership Agreements (EPA) between regional markets and the EU. The idea of EPAs faced immediately strong criticism from ACP-Countries - government and NGOs - because they would end the privileged status of the ACP and instead be based on free trade and reciprocal market access.

A new historical chapter of the Cotonou Agreement put emphasis on the "political dimension" in the relations between the ACP states and the EU. A comprehensive political dialogue should include all important issues of mutual interest, for instance new topics such as migration, conflict prevention, and organized crime. But the focus of the political dialogue was set by the Agreement on democracy, human rights and good governance. Respect for these principles was regarded as "essential" precondition for the future ACE-EU relations. In case of a country violating these essentials a mediation procedure was supposed to become activated and as an "ultimo ratio" the exclusion from funds and programs was possible. Although the extent of aid sanctions was remarkable over time (Schmidt 2008b), the use of political conditionality was incoherent and selective (Crawford 1998) (Note 7). Conditionality played an important role in the relations between the EU and African states. The most effective form of the political conditionality instrument - the membership perspective for neighbouring countries - was not relevant in relations with Africa. In general, the significance of conditionality has thus declined over the years. The EU-Africa strategy - the first strategy after 50 years of trade and development aid - adopted by the European Council end of 2005 reaffirms its commitment to democracy and human rights but does not explicitly mention 
conditionality. The EU favours reform-oriented countries by incentives and rewards further reform. The most prominent example is the EU-Governance Initiative which offers additional support for governance reforms with a total of 2,7bn Euro taken from the European Development Fund (EDF).

Africa's "first world war" - as Madeleine Albright, former U.S. Secretary of State termed the war in the Democratic Republic of Congo with over 4 million victims - forced the EU to give up its policy of non-intervention in Africa. For the first time the EU (Note 8) intervened in the DRC in 2003. The "Operation Artemis" was mandated by a UN Security Council Resolution. The aim of this small scale operation was to protect civilians against ethnic militias. Other small missions in the DRC, a mission to guarantee democratic elections in the DRC, and the EUFOR Chad/RCA (European Forces in Chad and the Central African Republic) followed. The EU-interventions were "bridging missions" which were taken over by UN-missions after some time.

Parallel to its comparatively low profile military interventions the EU became the most important supporter of African efforts to establish peace. Through the Africa Peace Facility the EU funds AU peace missions and logistics with 300 million Euro. EU support is also directed at strengthening the AU institutions: The Support Programme for the African Union includes 55 million Euro for the improvement of the institutional infrastructure of nascent AU institutions. It also includes a twinning program - the exchange of personnel between both institutions. The EU views the AU as a partner institution. Over the years a dense network of diplomatic contacts with the AU-EU Troika at the top has been established. The foreign ministers of the EU and AU-states met 15 times since 2003. In addition, permanent diplomatic representations have been established in Brussels, respectively in Adis Abeba. Both missions have become very active.

In general, the EU support for the AU is crucial for the AU because the AU funds are very limited and the efficiency of the AU structures suffers from a lack of organizational capacities. Therefore, it is not exaggerated to interpret the EU as the saviour of the AU (Schmidt 2008a).

\section{African Perceptions}

\subsection{The EU as a Promoter of Democracy and Human Rights in Africa}

The cooperation between the EU and Africa is based on a series of political documents and agreements covering the whole spectre of relations. Characteristic for all documents is a rhetoric stressing a partnership at eye level between the neighbouring continents. On the diplomatic level of heads of states and governments a broad consensus for the respect for democratic principles, human rights, and good governance is mirrored in the documents. This consensus is a central part of all resolutions and documents. Most importantly in this respect, is the key document The EU-Africa-EU Strategic Partnership together with its First Action Plan (2008-2010), agreed at the second EU-African Summit in Lisbon in 2007. The two documents define a comprehensive partnership covering four aspects of interregional relations: peace and security, governance and human rights, trade and regional integration, and key development issues. The Strategic Partnership document states that Africa and Europe form a "community of values" based on "the respect for human rights, freedom, equality, solidarity, justice, the rule of law and democracy". But the Lisbon Summit revealed also the limits of this consensus. A serious conflict emerged about whether Robert Mugabe, the Zimbabwean President, should participate in the summit. The EU had issued a travel ban for members of the Mugabe clan and high ranking officials because of severe human rights violations and the rigging of elections. The EU was strictly against his participation. But many African states declared solidarity with Mugabe. To avoid the cancellation of the summit, which had been postponed for years because of the Zimbabwe question, the EU lifted its travel ban and Mugabe participated. In protest the British Prime Minister refused to participate and it was left to German chancellor Angela Merkel to publicly criticise the Zimbabwean dictator. Many African heads of states and governments felt that the EU had no right to exclude Mugabe and accused the EU of discrimination and even complained about European intolerance.

The conflict also brought internal divisions between different EU members to the surface: Whereas Britain strongly opposed Mugabe's participation, Portugal and other member states were not willing to face the consequences if the summit would have to be cancelled. Against the background of the experience at the Lisbon summit fears increased that the third summit in Tripoli in November 2010 would lead to a repetition of the conflict, now in the case of Sudan: In 2009 the International Criminal Court issued an arrest warrant for Sudan's president Bashir on charges of war crimes and crimes against humanity in the Darfur province. The EU threatened to cancel the meeting if Sudanese President Bashir would participate. The Libyan authorities, afraid of a diplomatic conflict, banned Bashir from coming to Tripoli, although Libya had backed Bashir before. It was remarkable that there was virtually no protest from the AU members against Bashir's exclusion. 
These episodes reveal that the frequently invoked value consensus between Africa and the EU cannot be taken for granted. It is subject to the specific case and African solidarity against Western diplomatic interventions or sanctions, even in the case of a dictator like Mugabe, can easily be mobilized. The ambivalence of many African states and the AU toward democracy and human rights can also be seen in the Libyan civil war. On the one hand, the AU criticised the violence by Gaddafi's troops, but on the other hand the NATO military strikes were strongly criticised and not approved by the AU.

Another example for the fragile consensus on democratic norms and human rights is the widespread criticism in Africa against the International Criminal Court (ICC). Many African leaders and intellectuals argue that the ICC, which is strongly supported by the EU, is a Western imperialist attack especially on Africans (du Plessis 2008).

The conflict over Mugabe's participation at the Lisbon summit was exceptional in the sense that Africa governments usually shy away from openly criticising democracy and human rights policies of the EU or the USA. There are at least two reasons for this reluctance: First, public critique would affect the image of a government. Second, and more importantly, many African countries are highly dependent on aid from the West. In Mozambique, for instance, donors fund approximately 50\% of the state budget in spite of Mozambique often not meeting the development targets in the field of poverty reduction set by international donors and the government.

It is not surprising that African elites and intellectuals do not accept conditionality as a policy instrument. The practice by the EU and other donors to withhold funds or to postpone the disbursement of ODA in cases of human rights violations is criticised by African governments and civil society as selective and inappropriate because it would hit the poor and not the perpetrators. Africans often argue that they should have a say in using the conditionality instrument and that violations of human rights and democratic principles are foremost an African problem which should be addressed by Africans (Fioramonti 2009: 8-9).

Electoral assistance is to a much lesser degree a controversial instrument of democracy promotion (Motsamai 2010: 9-11). One reason for the greater acceptance is that the EU cooperates in this field with UNDP and sub-regional organizations or the AU. This increases the legitimacy of EU electoral support missions especially among civil society organizations. Since the AU and many African states lack financial and organizational resources, the EU has been asked by the AU to increase its support in capacity building and funding of AU-institutions. Although there is a demand for EU engagement in electoral assistance, the EU missions are often criticised. The critique is articulated on two levels: On the technical level, African NGOs and governments criticise the lack of funds and expertise available for election monitoring. The EU, critiques continue, focuses on the actual voting event and often does not pay attention to the campaign and whether there are equal and fair conditions for all candidates (so called level playing field-issues). A much more general critique complains about a paternalistic or even neo-imperialist behaviour of the EU (Motsamai 2010: 12). Much of this critique stems from different judgements about whether an election can be termed as free and fair. In particular, elections in Zimbabwe have caused tensions between EU and NGO observers and SADC and the South African electoral observation mission which were much more positive in their assessments than EU and independent NGO observer teams.

\subsection{The EU in the Eyes of South Africans}

The few available opinion polls (conducted in 2006-2007) reveal that South African citizens view economic growth and trade policies toward Africa as the two sectors where the EU has its greatest impact. Human Rights and Democracy are named by nearly $50 \%$ of the respondents as the third most important issue, but together with the Euro (see figure 1 in Fioramonti 2009: 9). The dominance of trade and economic issues might be explained by the Trade and Development Cooperation Agreement (TDCA) with the EU was finally signed at the end of 1999. Beside Egypt, South Africa is the only African country with a free trade agreement. The negotiations proved to be extremely tough. Under pressure from some member states, (France, Italy and Germany) the EU forced South Africa to give up brand names for agricultural products (Grappa etc.). This affected the EU image negatively (Olivier/Fioramonti 2010: 111). The EU regards the country on eye level, as a special case which has the disadvantage for the country that it is not fully eligible for European development funds. The strong position of South Africa with some competitive products on world markets provides the country with more independence and leverage in its foreign policy. This is one reason why South Africa has become a more self-conscious voice for Africa even in the G-20. 


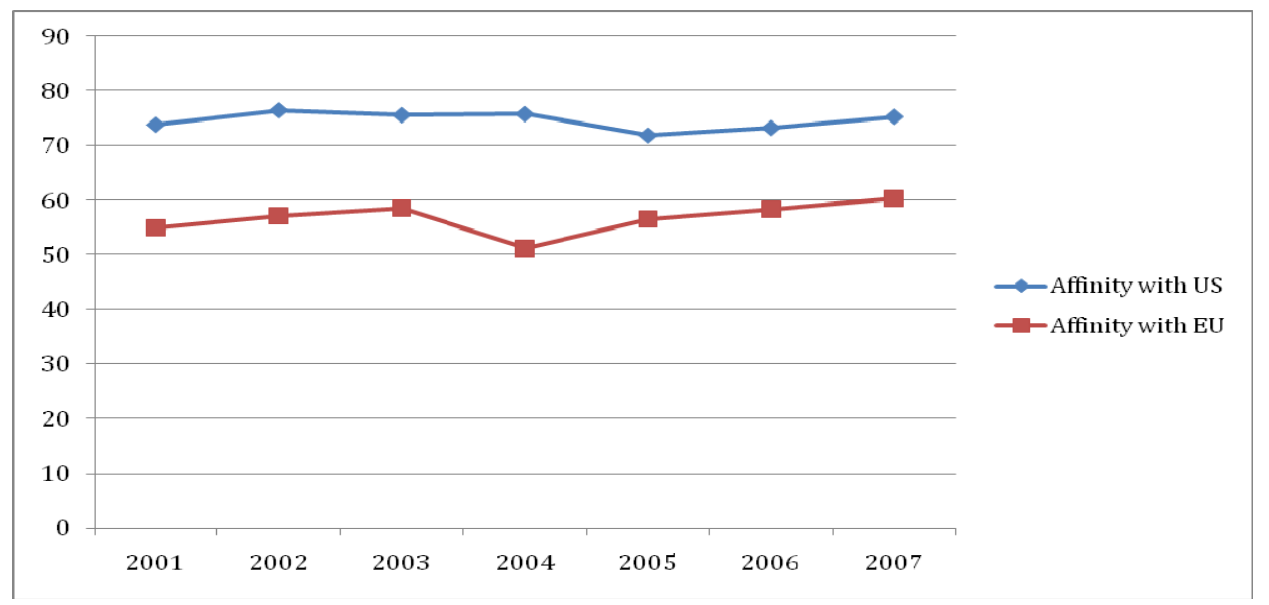

Figure1. Feelings of affinity for the US and EU among the Japanese, 2000-2006

Source: Japanese Cabinet Office, Gaikōnikansuruyoronchōsa, various

The relatively high prominence of democracy and human rights as an EU feature is a result of the role the EU played during the transition process. After the Soweto massacre in 1976 the EC started to condemn Apartheid. The EC protested against police brutality and took action with the Special Programme for Victims of Apartheid. Furthermore, a Code of Conduct for European companies doing business in South Africa was introduced and a moderate list of sanctions found consensus within the EC against British resistance and German reluctance (Schmidt 2007). The EC/EU provided also direct support for the negotiation process. A large-scale electoral observation mission for the founding elections of South Africa in 1994 was carried out. A wide bunch of positive measures - direct aid for institution building with a focus on the parliament, measures to anchor the rule of law etc. - was funded by the EU and individual member states.

There is a general contradiction in the EU-policy toward South Africa: Without doubts, many EU measures contributed to the democratic consolidation process of the county but the trade policy was not supportive of the process.

The analysis of South African perceptions stresses the role of the media. The image of the EU depends on media attention (Fioramonti 2009: 10-11). The two cases Fioramonti (2009) investigates, Kenya and South Africa show clear differences: The EU media coverage in South Africa is weak and events in British and American politics reveal more attention than EU politics. In Kenya the picture is different. Media coverage is more intensive with the result that over $40 \%$ of Kenyans view the EU as a global leader in peacekeeping and democracy promotion, much more than in South Africa (Fioramonti 2009: 10-11).

\subsection{Perceptions of the EU as a Global Power in Trade Relations}

A characteristic feature of EU-ACP relations is the connection between aid and trade. The EC/EU granted preferential market access for ACP countries to ease development efforts which were also directly supported by annual grants. African states and the AU states appreciate that the EU (EU Commission and member states together) are responsible for over $60 \%$ of ODA Africa receives.

When the EU announced to sign Economic Partnership Agreements (EPAs) with African regions an unprecedented conflict between the EU and many ACP countries emerged. The EU argues that its non-reciprocal trade relations with the ACP-countries are not compatible with WTO principles and that the trade relations have to adapt to the new global trade context. This means that EU will abolish trade preferences granted for decades to ACP-countries. According to the EU African countries should build regional entities with an internal liberalized market as a first step before free trade agreement would be signed between these groupings and the EU. The conflict over EPAs saw new lines of conflict. In contrast to issues of democratization the ACP governments received political support even from opposition parties, the overwhelming number of NGOs, from prominent Northern NGOs like Oxfam and from Western intellectuals engaged in development policies. This "coalition of the unwilling" received much attention and support from African and international media. The Namibian journalist Roux (2009) summarizes in a factual and detailed article on Namibia the African position. She argues that Namibia and other African governments are afraid of competition in case of necessary tariff reduction. She and many other authors view the EU policy as incoherent and unfair: Due to resistance from European farmers agricultural 
products are partly excluded from the list of duty- and quota-free export products. Elgström's (2007) study on the perceptions of the EU in the WTO Doha-negotiations reveals a similar judgement. He concludes from his expert interviews that the EU is "seen as a protectionist force in agricultural policy" (Elgström 2007: 956). In general, the image of the EU is described by him as a "super power in trade negotiations" (Elgström 2007: 962).

A continent-wide review undertaken by the African Trade Policy Centre (2007) gives also a broad list of arguments against the contents and the mode of the EU-African negotiations. Strong criticism is raised against a one-size-fits-all EU approach because the situation differs from country to country and post-conflict countries are not a priority for the EU. A general argument against EPAs is that the EU ignores the heterogeneity of Africa. Perceptions of the EU and EPAs depend on status and interests of various countries. African countries eligible for the Everything-but-arms-Initiative (Note 9) are less likely to resist EPAs. South Africa with its free-trade agreement was mentioned before. The neighbouring states, most of them members of the Southern African Customs Union (SACU) calculated that the introduction of an EPA would lead to massive tariff revenues losses, which make up a substantial share of government revenue. Especially Swaziland with over $60 \%$ and Lesotho with app. $50 \%$ of revenues are highly dependent on SACU revenues. Other resource-rich countries are in a much more comfortable position. African countries like Angola or Nigeria with huge oil production view China, India and even Brazil as alternatives with respect to trade and loans. Agreements with these and other countries are less complicated because aid and loans not subject to conditionality. Neither political or environmental, nor additional rules such as gender mainstreaming (in concrete development projects) complicate and postpone decisions for loans as in the case of the EU and most bilateral western donors. The new partner alternatives for African states have lead to stronger resistance against western policy including EPAs and weaker effects of conditionalities (Fioramonti 2009: 13). Another explanation, which cannot be tested here, argues that the ACP strong resistance is a result of disappointment that the EU did not offer any additional financial benefits to persuade ACP countries to sign an EPA.

Despite a diplomatic language style it is clear that the review carried out by the African Trade Policy Centre (2007) and many other documents and statements by African officials (African Union 2010) complain about a lack of will for compromise on the EU side. Postponed reactions by the EU on ACP proposals are interpreted as a non-responsive, even arrogant behaviour of the EU. Often Africans criticise strongly the diplomatic pressure from EU to sign Interim-EPAs. African interviewees participating in the negotiations perceived the EU negotiators patronizing and paternalistic. Elgström $(2010: 142 ; 146)$ explains the sharp criticism with two factors. First, he supposed that collective memories or traumas play a role. Second, the clear deadline for the negotiations (end of 2007) led to a tough negotiation style on the European side which was unprecedented in negotiations so far. In sum, there is a noteworthy discrepancy between the partnership rhetoric of official documents and the atmosphere in trade negotiations.

\subsection{The Perception of the EU's Role in Peace and Security}

The image of the EU's role in peace and security matters differs significantly from the field of trade. In general, the EU's engagement is highly welcome. AU statements regularly appreciate the EU's contributions (Sicurelli 2010: 185-186). During the last five years a dense cooperation framework between EU and AU bodies has emerged (Gänzle/Grimm 2010: 79-81). Without EU financial support through the African Peace Facility the AU would face huge difficulties to finance the interventions in Sudan (the Darfur crisis) and in Somalia. The AU and some critics from aid-organizations argue that funds should not be taken from the EDF (European Development Fund). ESDP military interventions are also welcomed by the AU if they are based on an agreement between both regional organizations. From both the EU and AU a UN-SR mandate is required to guarantee the legitimacy of military interventions. Fears from African and European states that the French-lead mission EUFOR Chad/RCA would be hijacked by narrow French interests have not been materialised although the operation guaranteed the survival of the government in Chad.

The slow progress in the establishment of the African Stand-by force and the regional brigades will maintain the AU's dependency on European military support. Of key interest for the AU are the 14 so-called Battle Groups each 1500 troop's strong fast response military units from different EU member states. So far, the EU has been very reluctant to discuss a possible Battle Groups mission and prefers to support African efforts to build up military capacities. The comprehensive EU-Engagement is driven by different motifs: For the EU, the geographical proximity plays a role for security reasons but also because the EU capacities to intervene are restricted. The EU also claims that it feels responsible for the neighbouring continent. The non-intervention in the Rwandan genocide, the dubious role France played in Rwanda, and the EU's mistakes in the Balkan wars are understood as a historical lesson. Another more political self-interest of the EU is that Africa is regarded as a kind of test arena for ESDP 
conflict management. Successful operations are prestigious and underline the EU's claim to be respected as a global actor with military capabilities. Given the widespread public reluctance for military interventions of any kind in Europe political support of the EU's role in peace and security matters in Africa cannot be taken for granted. Especially, in case a mission would meet severe difficulties or perceived as a failure.

\subsection{The EU as a Model for Africa?}

The AU institutions mirror the EU institutions to a surprising extent (Schmidt 2010: 28 table 2.1): There is a Pan-African Parliament and the European Parliament, the Assembly of Heads of States and Governments is similar to the EC Council, the African Court of Justice is equivalent to the European Court of Justice etc. But the similarities mask two core differences: The AU institutions are currently purely intergovernmental. There are no supranational institutions such like the EU Commission. The main reason for the intergovernmental construction of the AU lies in the belief in sovereignty. Due to historical experiences and to power interests of those in government, sovereignty is a "holy cow" for many Africans. But there are differences between African states. A recent study, a PhD dissertation by Martin Welz (2011), argues that the acceptance to give up or at least the will to curtail sovereignty depends on the form of the political regimes and the socialization of political elites: Democracies and democratic leaders are more eager to accept a loss of sovereignty. In addition, the mode of integration differs between the AU and the EU. The European integration followed largely, but not exclusively the neo-functionalist mode of integration whereas the AU comes closer to the federalist mode with the Constitutive Act at the heart of the integration. The $\mathrm{AU}$; in marked contrast to the EU, includes from the onset on security and peace matters.

Despite the obvious differences, the EU views its path of integration and its institutional setting as a possible model for the AU. The Union tries to strengthen the AU on different levels and to enhance its role in Africa and in the intercontinental diplomacy between Africa and Europe. Leading AU politicians have also expressed clearly their sympathy for the EU as a model (Sicurelli 2010: 186-187). In particular, the EU role is viewed and welcomed as a substantial contribution to AU peacekeeping efforts. Furthermore, many Africans admire the status of the economic integration in the EU.

\section{Summary}

African perceptions of the EU and its role in Africa are ambivalent. The perception of the EU depends on the field of cooperation. In general, the EU is regarded as a normative actor fostering values and a supportive force for African efforts to spread peace and security. The normative foreign policy components include the promotion of democratic principles, human rights, and good governance. Various activities and instruments to foster peace and security are also understood by Africans as value driven. With the exception of political conditionality there is not much critique in principle against democracy and peace promotion from the African side. But the concrete way the policies are carried out are often criticised. The self-attributed image of the EU as a promoter of values is to a considerable extent shared by Africans. The foreign policy identity of the EU manifesting in roles such as civilian power are supported and strengthened by Africans in certain issue areas. But the findings in the trade sector are not corresponding to the EU's self-proclaimed foreign policy identity. In trade relations the perception of the EU policy is much more critical. The EU is seen as a protectionist and paternalistic power with limited will for compromise and to respect African interests. Africans argue that in trade negotiations the EU shows a different face: The EU is perceived as a tough negotiator driven by economic interests and using instruments of coercion. Critics stems not only from governments, but also from the AU, sub-regional organizations and non-state actors. The main reasons for the ambivalent perceptions are the different roles the EU performs and policy incoherencies between democracy and peace promotion on the one hand and trade policy on the other hand. The EU is neither perceived exclusively as a soft power nor as a neo-colonial power. The limited character of the EU military interventions shows that the EU is risk-averse and clearly not motivated by neo-colonialist or neo-imperialist ambitions. But from a realist interpretation one could argue that the EU tries to increase its prestige and emphasis its actorness by military operations.

Against the background of a research gap these far-reaching judgements must be seen as tentative and preliminary. Despite the pioneering work of Fioramonti/Sicurelli (2010) and a few others we still lack data and more detailed analysis, especially on foreign policy discourses. Many questions remain open, for instance: In how far do legacies of the past (colonialism, imperialism etc.) shape perceptions or are they mobilised from time to time for domestic reasons or to set European negotiators under moral pressures? In how far is the idea of an EU-AU partnership more than "cheap talk" and internalized? Do Africans understand the fragmented character of EU foreign and security policy? What role does the media and the structure of the public realm play for African perceptions?

The field for further research is set. 


\section{References}

African Trade Policy Centre. (2007). EPA negotiations: African Countries Continental Review, Review Report. Retrieved March 2, 2011, from http://www.africa-union.org/root/au/AUC/Departments/ TI/EPA/DOC/Comprehensive_Review_of_EPAs_Negotiatons_in_Africa_ACP_Final_Report.pdf)

African Union. (2010). African Union's Conference of Trade Ministers held in Kigali, Rwanda on 29 October-2 November 2010. Retrieved March 2, 2011, from http://www.southcentre.org/index.php?option=com_con tent\&view=article \&id=1432\%3Asb52\&catid=144\%3Asouth-bulletin-individual-articles\&Itemid=287\&lang $=$ en

Bailes, A. K. (2008). The EU and a 'better world': what role for the European Security and Defence Policy? International Affairs, 84(1), 115-130. http://dx.doi.org/10.1111/j.1468-2346.2008.00692.x

Bono, G. (2006). The perils of conceiving EU Foreign Policy as a "civilizing" force. International Politics and Society, 1, 150-163.

Chaban, N., Elgström, O., \& Holland, M. (2006). The European Union as others see it. European Foreign Affairs Review, 11, 245-262.

Crawford, G. (1998). Human Rights and democracy in development cooperation. Towards fair and equal treatment? In M. Lister (Ed.), European development policy (pp. 131-178), Basingstoke: Palgrave.

du Plessis, M. (2008). The International Criminal Court and its work in Africa (no. 173). Pretoria: ISS Paper.

Elgström, O., \& Smith, M. (Eds.) (2006). The European Union's roles in international politics. London and New York: Routledge.

Elgström, O. (2007). Outsiders' perception of the European Union in international trade negotiations. Journal of Common Market Studies, 45(4), 49-967.

European Security Strategy. (2003). A secure Europe in a better world, Brussels. Retrieved May 3, 2011, from http://www.consilium.europa.eu/uedocs/cmsUpload/78367.pdf

Fioramonti, L., \& Lucarelli, S. (Eds.) (2010). External perceptions of the European Union as a global actor. London and New York: Routledge.

Fioramonti, L. (2009). African perceptions of the European Union: Assessing the work of the EU in the field of democracy and peacebuilding. Stockholm: IDEA.

Gänzle. S., \& Grimm, S. (2010). The European Union and the emerging African Peace and Security Architecture. In B. Hany (ed.). Crafting an African Security Architecture: Addressing Regional Peace and Conflict in the 21st Century (pp. 73-88). London: Ashgate Publ.

Hettne, B., \& Söderbaum, F. (2005). Civilian power or soft imperialism? The EU as global actor and the role of interregionalism. European Foreign Affairs Review, 10, 535-552.

Kotzé, H., \& Steyn, C. (2003). African elite perspectives: AU and NEPAD. Johannesburg: Konrad-Adenauer-Foundation Occasional Papers Series.

Maull, H. W. (2006). The perils of NOT conceiving European Foreign Policy as a civilian project. International Politics and Society, 1, 164-172.

Motsamai, D. (2010). The European Union's electoral assistance: perceptions of African democracy building. Stockholm: IDEA.

Olivier, G., \& Fioramonti, L. (2010). The emgering "global south". The EU in the eyes of India, Brazil and South Africa. In S. Lucarelli, \& L. Fioramonti (Eds.), External perceptions of the European Union as a global actor (pp. 105-119). London and New York: Routledge.

Roux, W. (2009). The Interim Economic Partnership Agreement: Why Namibia Should Not Sign - Part 1, 29 July 2009. Retrieved March 2, 2011, from http://www.afrik-news.com/article15985.html. Part 2: http://www.afr ik-news.com/article15990.html

Schmidt, S. (2007). The EU Democracy Assistance in Africa: The Cases of South Africa and the Democratic Republic of Congo (DRC), In A. Jünemann, \& M. Knodt (Eds.), Externe Demokratieförderung durch die Europäische Union. European external democracy promotion (pp. 33-52). Baden-Baden: Nomos. 
Schmidt, S. (2008a). Die EU als Retterin? Giga Focus 5/2008 (German Institute of Global and Area Studies, Hamburg). Retrieved March 2, 2011, from http://www.giga-hamburg.de/dl/download.php?d=/content/publi kationen/pdf/gf_afrika_0805.pdf

Schmidt, S. (2008b). Die Demokratie- und Menschenrechtspolitik der Europäischen Union. In M. Ferdowsi (Ed.), Afrika - ein verlorener Kontinent? (2nd ed., pp. 291-320). München: Bayrische Landeszentrale für politische Bildungsarbeit.

Schmidt, S. (2010). Through the lens of European integration theory: African peace and security architecture as a framework in transition. In H. Besada, (Eds.), Crafting an African Security Architecture: Addressing Regional Peace and Conflict in the 21st Century (pp. 15-36). London: Ashgate Publ.

Sicurelli, D. (2010). Regional partners? In S. Lucarelli, \& L. Fioramonti (Eds.), External perceptions of the European Union as a global actor (pp. 180-194). London and New York: Routledge.

Wæver, O. (2005). European Integration and Security: Analysing French and German Discourses on State, Nation, and Europe. In D. Howarth, \& J. Torfing (Eds.), Discourse Theory in European Politics. Identity, Policy and Government (pp. 33-67). Houndmills: Palgrave/MacMillan.

Welz, M. (2011). The African Union: Integration vs. Sovereignty (doctoral dissertation). University of Konstanz.

\section{Notes}

Note 1. An overview over the intensive economic, political and security relations is provided by chapter 4.2.

Note 2. This article focuses on Sub-Saharan Africa. The relations between the North African states and the EU have another quality because of geographic proximity, history and cultural factors.

Note 3. This reflects also my personal experience when I was teaching European politics at the University of the Western Cape in South Africa in 2003/04. My South African and my students from the neighbouring countries had only rudimentary knowledge of the EU in general and perceived the EU purely as an economic power. The EU image is often based on stereotypes such as Europe is a prosperous continent.

Note 4. Fioramonti's (2009: 12) surprising statement that African elites are aware of the character and structural limitations of the EU needs to be investigated. According to my experience this holds true only for a small portion of the elite - some academics and politicians with EU contacts or experience. Journalists are much less aware of the special construction of the EU.

Note 5. For instance, the Belgian colonialism of Leopold II was extremely brutal with millions of victims and the Portuguese settlers leaving Mozambique filled the capitals pipe system with concrete before they left.

Note 6. In 2007 renamed in European Instrument for Democracy and Human Rights (EIDHR), see alsohttp://ec.europa.eu/europeaid/what/human-rights/index_en.htm.

Note 7. A fair or better comprehensive assessment about whether the EU democracy promotion in Africa is successful would require a comparative analysis with the Africa policy of the U.S., France, and the UK for example.

Note 8. EU-member states, in particular France, had intervened militarily more than a dozen times to serve French interests by supporting political regimes under pressure from guerrilla movements or internal opposition.

Note 9. This EU initiative guarantees duty-free and quota-free access for exports from Least Developed Countries. 